\section{DIGITAL COMMONS \\ @ UNIVERSITY OF SOUTH FLORIDA}

\section{ABO: Interactive Journal for Women in the Arts, 1640-1830}

Volume 9

Issue 1 Special Issue: Eighteenth-Century Camp

Article 3

2019

\title{
Neoclassicism and Camp in Sir William Hamilton's Naples
}

\author{
Ersy Contogouris \\ Université de Montréal, ersy.contogouris@umontreal.ca
}

Follow this and additional works at: https://digitalcommons.usf.edu/abo

Part of the Dramatic Literature, Criticism and Theory Commons, Feminist, Gender, and Sexuality Studies Commons, and the Literature in English, British Isles Commons

\section{Recommended Citation}

Contogouris, Ersy (2019) "Neoclassicism and Camp in Sir William Hamilton's Naples," ABO: Interactive Journal for Women in the Arts, 1640-1830: Vol.9: Iss.1, Article 3.

https://doi.org/10.5038/2157-7129.9.1.1176

Available at: https://digitalcommons.usf.edu/abo/vol9/iss1/3

This Scholarship is brought to you for free and open access by Digital Commons @ University of South Florida. It has been accepted for inclusion in ABO: Interactive Journal for Women in the Arts, 1640-1830 by an authorized administrator of Digital Commons @ University of South Florida. For more information, please contact digitalcommons@usf.edu. 


\title{
Neoclassicism and Camp in Sir William Hamilton's Naples
}

\begin{abstract}
Susan Sontag, in her now-classic "Notes on Camp" (1964), traces the origins of camp to the eighteenth century $(13,14,33)$. And although it is precisely the baroque and rococo art movements against which Winckelmann rebelled that Sontag identifies as camp, it is worth reflecting on whether the notion of imitation that is central to both movements - imitation of ancient works in the case of neoclassicism, and imitation as parody in the case of camp (Meyer 7) - might not bring the two closer. Once the conceptual chasm separating neoclassicism and camp has begun to be bridged, we can push our enquiry further and ask to what extent camp can be read into the neoclassical movement.

The endeavour might seem anachronistic since the word "camp" only made its appearance in the English dictionary at the beginning of the twentieth century. To paraphrase the English literature scholar Devoney Looser in her study of "Jane Austen Camp," I am not asking if camp is "there" in the development of neoclassicism. What I am doing is asking what aspects of neoclassicism (if any) can be read differently if we look at this moment through a campy lens. To do so, I propose to consider two series of spectacles that Sir William Hamilton, the British ambassador to Naples from 1764 to 1800, presented to his guests, the many European aristocrats, diplomats, Grand Tourists, artists, and other travellers who made their way to Naples in their search for the unique classical experience provided by a visit to Pompeii and Herculaneum. One was of his wife Emma Hamilton's famous Attitudes; the other was the less well-known display he organized of adolescent boys splashing in the waters in what might be thought to have approximated ancient gymnopaedias.
\end{abstract}

\section{Keywords}

camp, neoclassicism, Emma Hamilton, Naples, Grand Tour, antiquity

\section{Creative Commons License}

\section{c) (7) (8)}

This work is licensed under a Creative Commons Attribution-Noncommercial 4.0 License 
In its excess and exuberance, camp seems far removed from the "noble simplicity and quiet grandeur," to quote the German art historian and archaeologist Johann Joachim Winckelmann (35), that we have come to associate with the neoclassical movement. In his highly influential Reflections on the Imitation of Greek Works in Painting and Sculpture (1755) and History of Ancient Art (1764), Winckelmann formulated the neoclassical ideal and thus decisively impacted the development of neoclassicism in Europe. He argued that in order to create great works of art, to attain the beau idéal, contemporary artists should turn away from the excesses of the Baroque and Rococo, and seek instead to imitate the ancients. Central to his vision was that artworks should be constructed along the classical principles of symmetry and harmony and refrain from showing exaggerated emotions. The argument expounded by Winckelmann and his followers in favour of the "true style," as Neoclassicism was then called, was both aesthetic and ethical: the imitation by contemporary artists of the sobriety and restraint that were seen as the hallmarks of classical art would result in works that were universal, atemporal, eternal, and morally edifying (Honour, Cramer, Eisenman).

Camp, on the other hand, avails itself of precisely the opposite: exaggeration and excess. Camp does not profess to provide an example of good conduct, nor does it lay any claim to timelessness or universality. Camp lacks a foundational text such as Winckelmann's and has no precise delineation. Scholars differ, for instance, as to whether it is a mode of performance that should be understood as pertaining strictly to the male gay community (Meyer) or whether it is present in wider circles (Robertson). In a confirmation, perhaps, of the observation by Charles Kennedy the gay protagonist in Christopher Isherwood's novel The World in the Evening (1954) ${ }^{1}$ - that camp is "terribly hard to define" (106), scholars disagree as to whether camp should in fact be precisely defined or whether it should be understood as a more elusive notion. In his book Masculinity and Queer Desire in Spanish Enlightenment Literature (2016), Mehl Allan Penrose provides a possible explanation for this difficulty: "It [camp] is so difficult to define because it is much like judging beauty. Camp rests partially in the eyes of the beholder" (83). The guest editors of the present issue of $A B O$ have opted for this more indeterminate understanding, as have many of its contributors. In their introduction, Ula Klein and Emily Kugler have chosen to present camp mainly through stylistic characteristics (silly, extravagant, ridiculous, exaggerated, affected ... ), while also rooting it firmly in the European long eighteenth century and, more specifically, in eighteenth-century constructions of gender and sexuality. In this sense, they accord neither with the depoliticization of camp nor with the understandings of camp as relating specifically to male gay culture, but identify camp as "a queer mode of performance" (see also Cleto), a positioning with which I agree. While Klein and Kugler rightly acknowledge the limitations of Susan Sontag's "Notes on Camp" 
(1964), the use they (and I) make of camp as a lens nevertheless flows from Sontag's seminal text and builds upon it.

While scholars writing about camp do not arrive at a consensus regarding its definition, all notions of the term since its first recorded use in 1909 identify camp with an "over-the-top aesthetics" (Horn 2), of which exaggeration, artifice, outrageousness, and excess are among the core characteristics (Halperin, Meyer, Sontag). These characteristics would seem to locate camp at the polar opposite of neoclassicism. At the same time, there are some features of camp and neoclassicism that might encourage us to re-examine this view and to consider what might happen if we attempt to bring them into closer dialogue with one another. Although the word "camp" only made its appearance in English at the beginning of the twentieth century, Sontag traces the origins of camp to Baroque and Rococo art forms of the seventeenth and eighteenth centuries (280-1, 286), a positioning on which this volume is premised. Sontag's identifying of the beginning of camp to the Baroque and Rococo does not mean she equates camp with these art movements. However, it does mean that unlike many later writers on camp (Halperin, Horn, Meyer), she does not see parody as a central component of camp. ${ }^{2}$ It is precisely against the Baroque and Rococo that Winckelmann rebelled; nevertheless I agree with German literature scholar Alice A. Kuzniar that we can find camp inflections in his writings. Highlighting passages such as Winckelmann's famous description of a painting featuring Jupiter kissing a naked Ganymede, the sixteen-year old mortal boy of whom the god became enamoured and whom he abducted - "I find nothing that can compare with this face, so much voluptuousness [Wohllust] blossoms forth from it that his whole life seems to be solely one kiss," he writes ${ }^{3}$-Kuzniar recognizes the possibility of "[reading] Winckelmann with camp sensibility, so overt and clinically detailed are his depictions of eroticized body parts, from the full, feminine buttocks of a Bacchus to the contours of the nipples ... on a male torso" (11). We might also argue that the notion of imitation that is so central to Winckelmann's aesthetics also brings him within the realm of camp: his assertion that "The only way for us to become great or, if this be possible, inimitable, is to imitate the ancients" (5; my emphasis) carries within it an element that could be described as campy in the ever greater bidding up and exceeding that it expresses and to which it aspires.

Once the conceptual chasm separating neoclassicism and camp has begun to be bridged, we can push our enquiry further and ask to what extent camp can be read into the neoclassical movement-indeed, if we can identify a camp component in neoclassicism-specifically around the time Winckelmann was publishing his writings and in the generation that immediately followed him. To do so, I propose to consider two series of spectacles that Sir William Hamilton, the British 
ambassador to Naples from 1764 to 1800 , presented to his guests, the many European aristocrats, diplomats, Grand Tourists, artists, and other travellers who made their way to Naples in search of the unique classical experience provided by a visit to Pompeii and Herculaneum. One was of his wife Emma Hamilton's famous Attitudes; the other was the less well-known display he staged of adolescent boys splashing in the waters in what might have approximated ancient gymnopaedias.

My argument is that while both these spectacles can be considered campy in that they propose "[ways] of seeing the world as an aesthetic phenomenon" (Sontag 277), as well as in their erotics, theatricality, artifice, stylization, exaggeratedness, and general over-the-topness, they were nevertheless not antithetical to neoclassical aesthetics. On the contrary, I argue that they should be seen as part of a continuum of experiences in the lives of Sir William and his circle, a continuum that included the sublimated judgements of universal beauty expounded by the champions of the developing neoclassical aesthetic, the homoerotic and pederastic scenes discovered on walls and vases at Pompeii and Herculaneum, and the erotic poses and dancing performed by prostitutes in high-class London brothels. The concept of camp helps us shed light on the confluence of desire, gender, sexuality, and class at this time and in this environment, a relationship that is also examined by Julie Beaulieu in her article in this issue. Using the lens of camp, we can both reinscribe these issues at the very root of neoclassicism and recognize their later recurrence, for instance in the nineteenth-century trope of sculptures of Neapolitan fisherboys.

\section{Emma Hamilton's Attitudes}

As impresario of the British court in Naples, Sir William offered his guests spectacles that continually stimulated their erotic gaze. On most evenings after dinner, he treated his guests to his wife's celebrated Attitudes. Dressed in classical garb, the famously beautiful, sensual, and alluring Emma Hart (later Hamilton) adopted poses that brought to mind mythological, religious, and literary figures from classical statuary, grand master works, and paintings found on ancient vases and on the recently excavated walls at the nearby archaeological digs. ${ }^{4}$

In quick succession, Emma performed sometimes over two hundred such poses (Rokeby 281-2). As the English traveller and writer John Morritt of Rokeby, who visited Naples in 1796, described it,

She takes almost every attitude of the finest antique figures successively and varying in a moment the folds of her shawls, the flow of her hair; and her wonderful countenance is at one instant a Sibyl, then a Fury, a Niobe, a Sophonisba drinking poison, a 
Bacchante drinking wine, dancing, and playing the tambourine, an Agrippina at the tomb of Germanicus and every different attitude of almost every different passion. (281)

For the Grand Tourists and other travellers who had come to Naples and its newly excavated ancient cities in search of "a closer communion with the ancient past" (Hales and Paul 1), Emma's Attitudes became one of the requisite Neapolitan experiences. The portraitist and history painter William Artaud, who visited Italy in 1796 as a Royal Academy scholar, wrote to his father, "The environs of Naples are truly Classic Ground. ... I have been at Herculaneum \& Pompeii \& the Museum at Portici, \& saw Lady Hamilton's attitudes" (qtd. in Jenkins and Sloan 261). And for spectators familiar with classical theatre, Emma's Attitudes would have recalled the ancient art of pantomime (see Lada-Richards; Touchette). Although some spectators described the performance as scandalous (Cox 171), the classical dimension of the Attitudes seemed to have provided-for most viewers - a counterpoint that rendered it acceptable for the wife of the English ambassador to display her body in such a way.

Born in dire poverty in or around 1765 (the precise events of her life are unclear), Emma had been sent at a very young age to work in service. She had ended up in London, where, at the age of fifteen, she is believed to have joined Miss Kelly's, one of the city's most glamorous brothels. In order to ensure that her "girls" proved suitable companions to her aristocratic clients, the procuress Miss Kelly had them tutored in music, languages, and the less lofty performances of erotic postures and dancing (Williams 60-2), the latter of which earned them the nickname of "posture molls." Emma is also believed to have worked at the quack doctor James Graham's "Temple of Health," where the main attraction, the "celestial bed," promised healthy and beautiful babies to infertile couples willing to spend $£ 50$ and a few hours on it. The room in which stood this bed was decorated with flowers, doves, cupids, and live young women who "appeared in scanty classical garb and assumed various provocative poses" (Cox 170). In both establishments, Emma would have learned to perform erotic poses, combining them, in the case of the Temple of Health, with a classical vocabulary.

From there, Emma began her social ascent. She became the mistress of the minor aristocrat Sir Harry Fetherstonhaugh in 1781, and then the following year, of Charles Greville, son of the Earl of Warwick and nephew of Sir William Hamilton. After four years, wanting to put an end to the liaison, Greville sent her to Naples to his uncle, where she became first Sir William's mistress and then his wife. It is there that Emma began to perform her Attitudes, again combining classicism and erotic posing in a vision or construction of femininity made up of a collage of 
characters that she appropriated from high culture.

Travellers' journals and letters indicate that Emma's performances were widely appreciated. Indeed, spectators commented on the many ways in which Emma seemed to embody, in her Attitudes, the classical ideal: Lady Elizabeth Foster, for instance, who watched Emma attitudinize in London in 1791, described her as "draped exactly like a Grecian statue, her chemise of white muslin was exactly in that form, her sash in the antique manner" (qtd. in Tours 90). At the same time, Emma's Attitudes were also praised for qualities that were decidedly less associated with classical values, and that could be described as camp in their theatricality and excess. The German poet, playwright, and essayist Johann Wolfgang von Goethe, for instance, who stayed with the Hamiltons during his travels through Italy, praised the variety of her expressions, which he listed breathlessly in his description of the Attitudes: "serious, sad, playful, ecstatic, contrite, alluring, threatening, anxious" (199-200). Others were troubled by this expressiveness, which they perceived as excessive and therefore antithetical to the classical ethos. The connoisseur, wit, and man of letters Horace Walpole (himself no stranger to camp") wrote, "I have not seen her yet, so am no judge; but people are mad about her wonderful expression, which I do not conceive; so few antique statues having any expression at all, nor being designed to have it" (XI, 338) — an expressiveness, in other words, that was at a far remove from the Winckelmannian ideal of quiet grandeur. Exaggeration of expression; appropriation, mimicry, parody, and pastiche of different cultural forms and languages; "repetitive and stylized acts" (Meyer 3); in these ways, Emma's Attitudes present themselves as unmistakably camp.

And yet, her performances became instrumental in the spread of the neoclassical aesthetic, thanks in large part to her fame, but also to the dissemination of a series of twelve plates published in 1794 after drawings by the German portraitist and historical painter Friedrich Rehberg (figs. 1, 2, 3). ${ }^{6}$ Rehberg had trained in Rome with Winckelmann's friend, the neoclassical painter Anton Raphael Mengs. The plates were etched by Tommaso Piroli, who, in the previous year, had executed the prints for John Flaxman's two Homeric series, The Iliad and The Odyssey. 


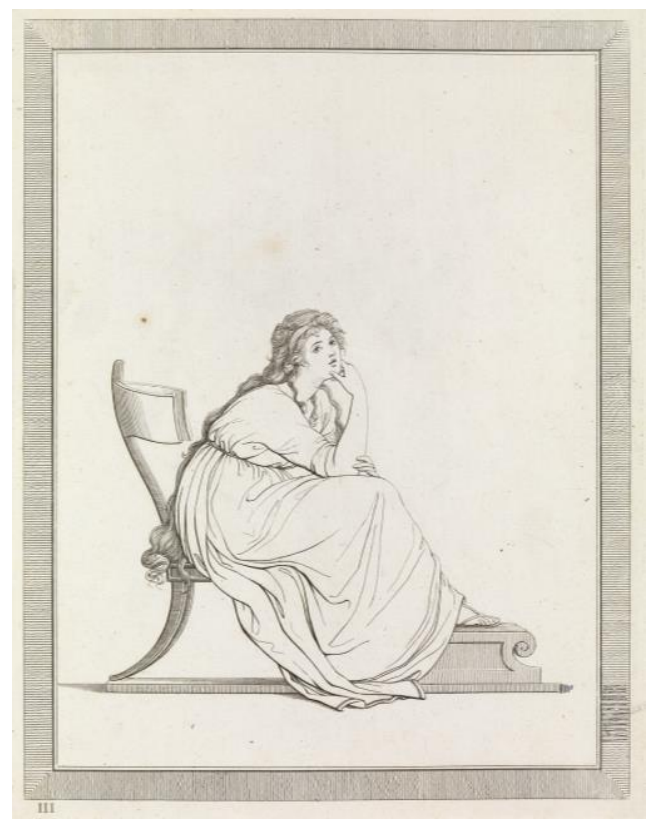

Figure. 1. Tommaso Piroli (c. 1752-1824), after Friedrich Rehberg (1758-1835), Drawings Faithfully Copied at Naples..., 1794. Plate 3. Etching, $26.9 \times 20.8 \mathrm{~cm}$. Greenwich, London, National Maritime Museum (PAD3218). (CC BY-NC-ND 3.0)

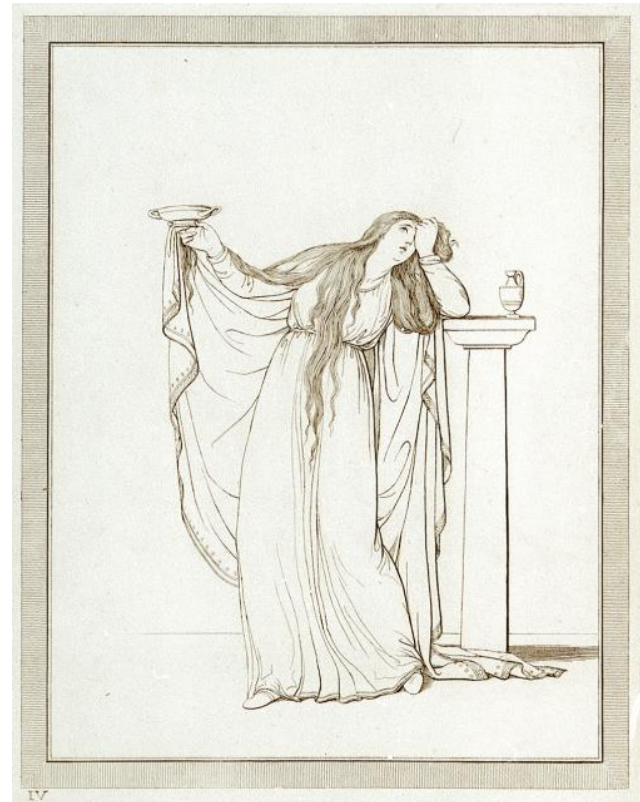

Figure. 2. Tommaso Piroli (c. 1752-1824), after Friedrich Rehberg (1758-1835), Drawings Faithfully Copied at Naples..., 1794. Plate 4. Etching, $26.9 \times 20.8 \mathrm{~cm}$. 
Greenwich, London, National Maritime Museum (PAD3219). (CC BY-NC-ND 3.0)

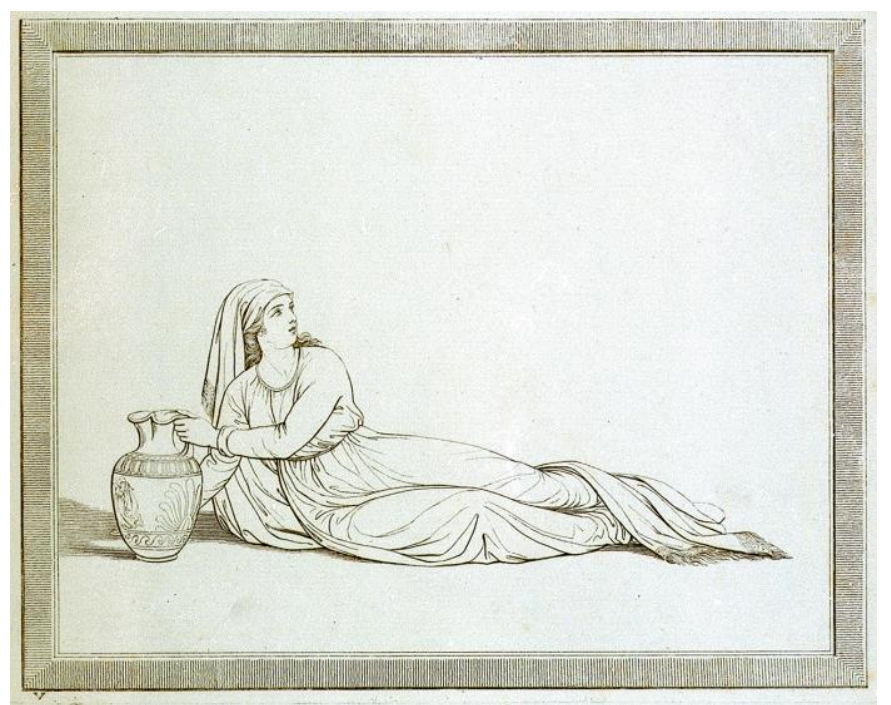

Figure. 3. Tommaso Piroli (c. 1752-1824), after Friedrich Rehberg (1758-1835), Drawings Faithfully Copied at Naples..., 1794. Plate 5. Etching, $26.9 \times 20.8 \mathrm{~cm}$. Greenwich, London, National Maritime Museum (PAD3220). (CC BY-NC-ND 3.0)

The prints after Rehberg display an aesthetic of simplicity and linear purity that is characteristic of neoclassicism. They record some of the features of the Attitudes and jettison others in order to reconstruct Emma Hamilton into an ambassadress of neoclassicism. Her sensuousness and three-dimensionality are eviscerated by the etchings' linearity and lack of modelling. Her movements are frozen, as if contained by the boxes that frame each print. While this is the version of Emma's Attitudesand of neoclassicism - that has come down to us today, one in which the campier aspects of the performance have been snuffed out, we must not ignore the campy exuberance and exaggeration that characterized the Attitudes and that is recorded again and again by Emma's contemporaries in their appreciations of her performances.

\section{Neapolitan fisherboys}

There was another spectacle that Sir William offered his guests, one that has been forgotten in the narrative of the Hamiltons' life in Naples. On many afternoons, Sir William hired young boys to splash in the shallow waters at his seaside villa in the Neapolitan neighbourhood of Posillipo. Goethe (again) described these displays in his journals: 
The day before yesterday I visited Sir William Hamilton in his Posillipo villa. There is really no more glorious place in the whole world. After lunch, a dozen boys went swimming in the sea. It was beautiful to watch the groups they made and the postures they took during their games. Sir William pays them to give him this pleasure every afternoon. (353)

As with Emma's Attitudes, we get a sense here from Goethe's use of phrases such as "the groups they made" and "the postures they took" that there was something highly stylized and theatrical about these spectacles, an "over-the-top aesthetics" and "queer mode of performance" of gender that we can characterize as camp.

In the late eighteenth century, Naples was known as a place where boys were available to tourists for hire. It is likely that young boys were made vulnerable to prostitution because of the economic hardship of so many Neapolitan families. ${ }^{7}$ For the aristocratic Grand Tourists and other visitors to Naples, this meant the possibility of exploring and assuaging desire not just for male bodies, but for lowerclass male bodies, a class transgression that was also manifest in their desire for Emma's body.

The excavations of the buried sites of Pompeii and Herculaneum had unearthed a significant number of homoerotic and pederastic scenes on walls and vases, as well as phallica and other erotica (fig. 4). In his study of homoerotic art collecting in the eighteenth and nineteenth centuries, the queer theorist and art historian Whitney Davis examines the circle of connoisseurs around Sir William, which included Winckelmann. ${ }^{8}$ He argues that with Winckelmann, whose writings served not only as the core texts of neoclassicism, but as the foundation of the discipline of art history, the judgment on which universal artistic beauty was founded was homoerotic and specifically pederastic. What can be traced back to the core of Western art history then - and as an optimal offering chez Sir William-is pederastic desire, sublimated into judgments of universal beauty and what Davis calls "non-sensuous (rational and moral) approbation and admiration" (252). It is this process of sublimation that meant that the young boys splashing about for the benefit of Sir William's guests could be appreciated both erotically and aesthetically. 


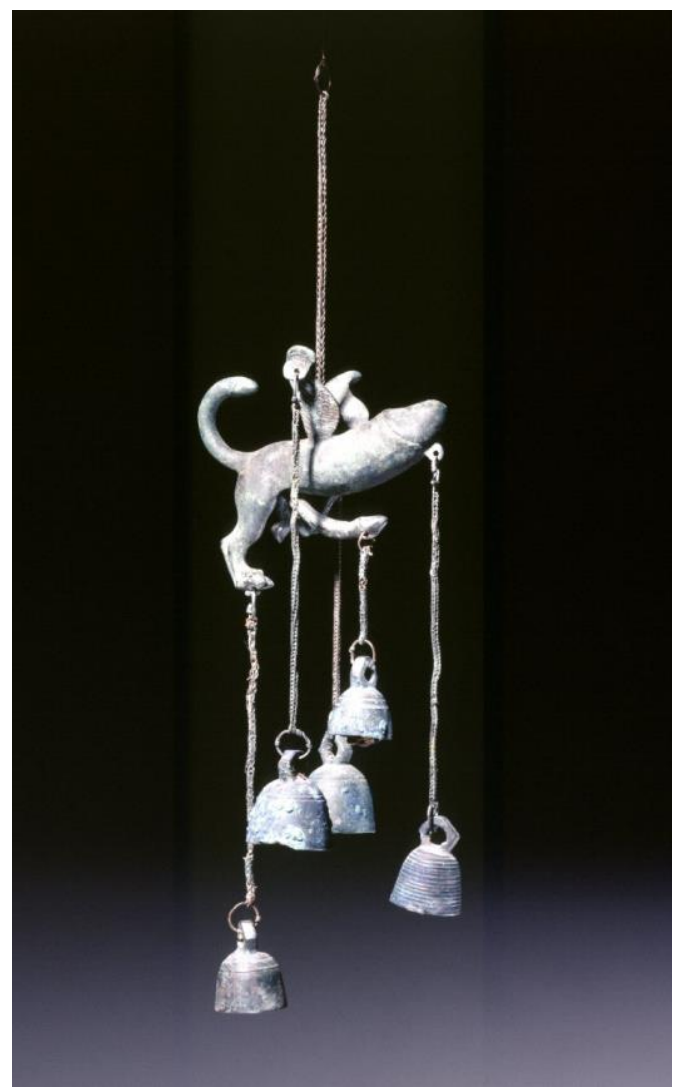

Figure 4. Bronze phallic wind chime (tintinabulum). Roman, 1st century CE. Length: $13.5 \mathrm{~cm}$. London, The British Museum (GR 1856.12-26.1086). (CC BYNC-SA 4.0)

And it is because of this same process that this spectacle was considered appropriate even for women to watch. The French painter Élisabeth Vigée-Le Brun recounts, in her memoirs, witnessing these young boys diving in the water:

Sir William Hamilton had a small casino on the shore where I frequently dined. He used to throw pence into the sea for young boys to dive for, and when I had begun to tremble for their safety, as they remained so long under the water, they would re-appear triumphantly holding the money in their mouths. (155)

As with Emma's Attitudes, the classical dimension of these spectacles, the possibility of appreciating them in a sublimated way, ensured that they were deemed acceptable for mixed company, but it also provided a focus away from their campier aspects for those who might not have wanted to (or known how to) engage with them. At the same time, in Vigée-Le Brun's emotive response with regards to 
the safety of the young boys, we find what Sontag described as camp in the period's "taste for the picturesque and the thrilling" (280).

The vein of pederastic eroticism found in Pompeiian art and in Hamilton's display of boys survived into the following century, when the Neapolitan fisherboy became a trope of nineteenth-century sculpture. Philippe Durey explains away the trend for fisherboys as a simple bucolic reverie: "This smiling vision of the bodies of adolescents should be seen as a vindication of a simple life in touch with a nature that is meant to be serene and welcoming" (354; my translation). Yet it is clear that there is something more at play. In these works, what Fred Licht has called "the equivocation between high ideal and raw sexuality" that was to become "a hallmark of modern speculations on the theme of nakedness" (186) reflects an assimilation and continuation of the aesthetics / erotics of Sir William's circle. In this way, the Neapolitan fisherboys of nineteenth-century sculptors such as François Rude, Francisque-Joseph Duret, and Jean-Baptiste Carpeaux harkened back to works such as the Herculaneum lamp ornament representing a dancer.

The boys in these works display a similar mode of performance of gender and sexuality as Sir William's Posillipo boys. They are naked, except for Duret's, who wears short pants. They all wear the traditional Neapolitan fishermen's bonnet on their heads. Resembling the cap worn by Ganymede, the young boy with whom Jupiter had fallen in love, it therefore associates the fisherboys with the myth of Jupiter and Ganymede, and in this sense serves perhaps to sanction pederastic desire (Goodman; Hertz). Identified, moreover, with the French Revolution, the Phrygian bonnet, so named because Ganymede came from the kingdom of Phrygia, might also have signalled a form of liberation from restrictive social and cultural mores.

The sculpting of a fisherboy was almost a necessary rite of passage, so that Rude, Duret, and Carpeaux all produced their versions at crucial moments in their careers, when they were beginning to establish their reputations. Even the Realist painter Gustave Courbet attempted a rendition in the only sculpture he ever sent to a Salon. Antoinette Le Normand Romain explains that Naples was a formative stop for young sculptors visiting Italy because of the archaeological museum in that city, and that, although they might have been repelled at first by the city's noise and dirt, they eventually found inspiration in it (55). The recurrence of sculptures of these young, campy, specifically Neapolitan, fisherboys also invites us to consider the particular ways in which Naples and its environs might be thought of as a camp place (Drushel and Peters).

Rude showed a preliminary version of his Jeune pêcheur napolitain avec une tortue at the 1831 Salon. Two years later, he exhibited the final version and was awarded 
the Cross of the Legion of Honour. His fisherboy was to become one of the most successful sculptures of the nineteenth century. Duret exhibited his fisherboy, Jeune pêcheur dansant la tarentelle, also at the Salon of 1833. He had just returned to Paris from Italy where he had sojourned after being awarded the Prix de Rome. Thanks to this work, he received the Medal of Honour and became a member of the Legion of Honour (Hargrove 247). As a strategic homage to the work of these two sculptors, Carpeaux sent his Pêcheur napolitain à la coquille (1857-after 1861; fig. 5) to Paris as his first envoi de Rome, the second-year project at the Academy. The recognition and celebration of the vein of pederastic desire at the core of Western art history's foundational moment became in turn a key foundational moment in the careers of these sculptors.

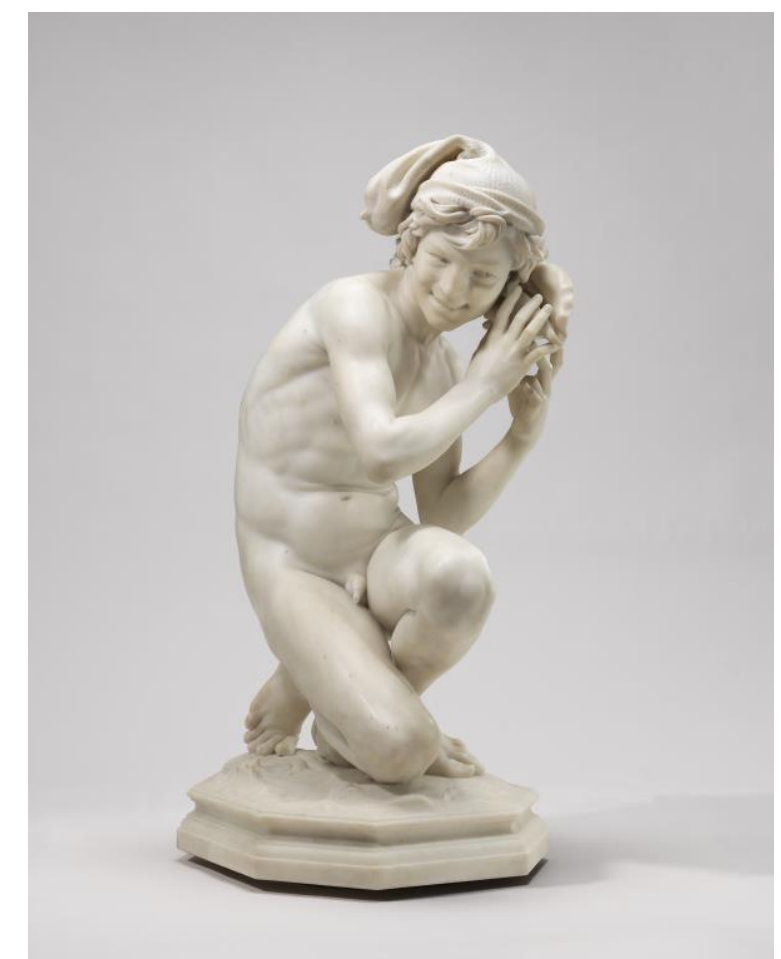

Figure 5. Jean-Baptiste Carpeaux (1827-75), Pêcheur napolitain à la coquille, 1857-after 1861. Marble, 92 x 42 x $47 \mathrm{~cm}$. Washington, DC, National Gallery of Art, Samuel H. Kress Collection (1943.4.89). Courtesy National Gallery of Art, Washington.

Gustave Courbet produced his own Realist version of the trope in his $1862 \mathrm{Le}$ pêcheur de chavots (fig. 6). Instead of Naples, Courbet chose a local setting: the title informs us that the boy is fishing "chavots," usually referred to as "chabots," the local name for sculpin, a fish found in the Loue River near Courbet's home 
town of Ornans. John Hunisak places Courbet's Pêcheur in the vein of the earlier sculptures of Rude, Duret, and Carpeaux, despite the title that identifies the figure with the Franche-Comté. He argues that the Pêcheur is as exotic as these earlier works and that it exhibits the same "ideal nudity and "fisherboy charm" (52). Courbet's fisherboy may be naked, but his nudity is not classically ideal. His flesh is dull and his musculature is slack. He displays neither the exoticism nor the eroticism of his Neapolitan counterparts. Rather, Le pêcheur de chavots shares more with the toiling boy in Courbet's Stonebreakers (1849) than with Rude's, Duret's, and Carpeaux's smiling figures, and his fisherboy might be read as his attempt to produce the first Realist sculpture. But in spite of the important differences between Le pêcheur de chavots and the Neapolitan fisherboys, what is significant is that Courbet undertook the trope of the naked adolescent fisherboy at an academic moment in his career. In December 1861, Courbet had finally relented to pressure from his admirers and supporters and had established a studio. ${ }^{9}$ It is therefore to the fisherboy trope that he turned at this key moment in his career, when he founded a studio, an act that confirmed his position as the head of a school, and at a foundational moment for the history of Realist sculpture. Courbet's strategic appropriation of the trope of the naked adolescent fisherboy shows he understood its significance in the history of Western art. 


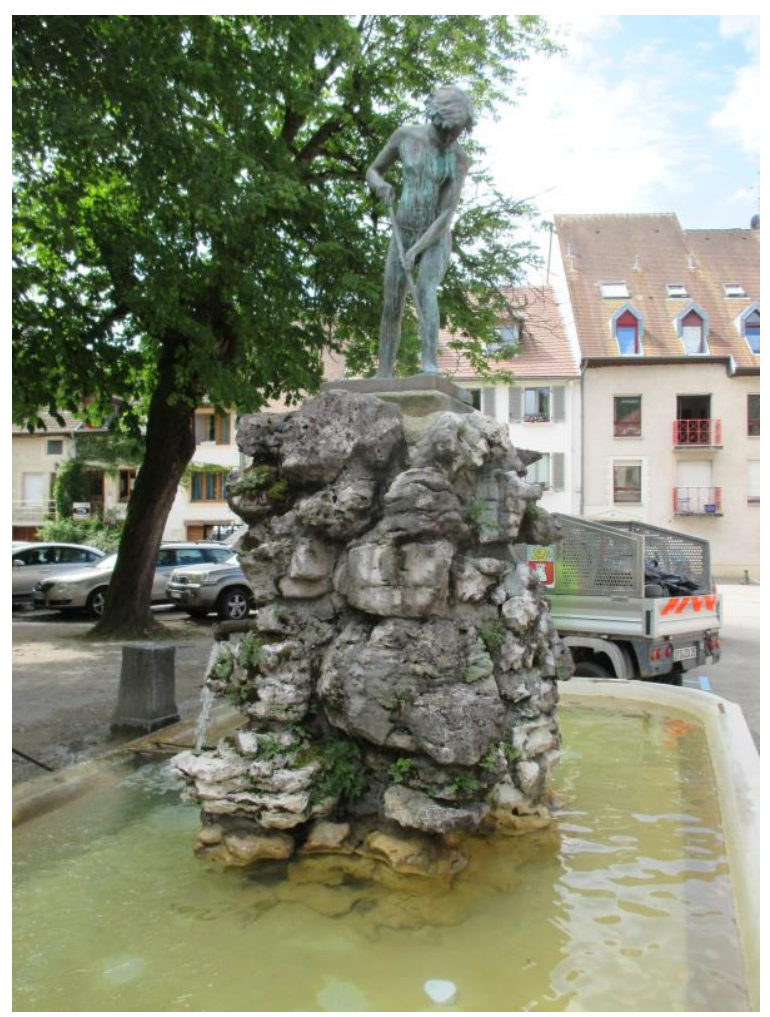

Figure 6. Gustave Courbet (1819-1877), Le Pêcheur de chavots, 1862. Bronze, height: $120 \mathrm{~cm}$. Ornans, place Courbet. Photo: Arnaud 25. (CC BY-NC-SA 4.0)

The exploration of classicism and camp, of the aesthetics and erotics of antiquity through the depiction of adolescent boys continued into the twentieth century in the works of the German photographer Wilhelm von Gloeden, who lived in Naples for a few months before moving to the nearby island of Taormina. Von Gloeden's photographs (fig. 7) can be read as a furtherance of the desire that had been on display for Sir William Hamilton's guests, presented once again in an aesthetic that can only be described as stylized, theatrical, and over-the-top, characteristic of camp. And as with Sir William's spectacles of young boys splashing in the Posillipo waters, it is a homoerotic, specifically pederastic, desire that is expressed. In his photographs of naked teenage boys, von Gloeden uses the language of classical antiquity, as had been done previously with the performances of Emma's Attitudes and with the Posillipo boys, "to mask what could otherwise arouse the ire of the censors with a veil of classical learning" (Gloyn). While Roland Barthes ultimately argued that von Gloeden's photographs should be considered as kitsch, not camp, because of the way they overload "the code of antiquity" and combine different kinds of "signs without thinking about it" (qtd. in Russell 60), some scholars, such as the feminist historian of photography Anne Marsh, are not so quick to draw a 
firm separation between camp and kitsch in relation to von Gloeden's photographs (146).

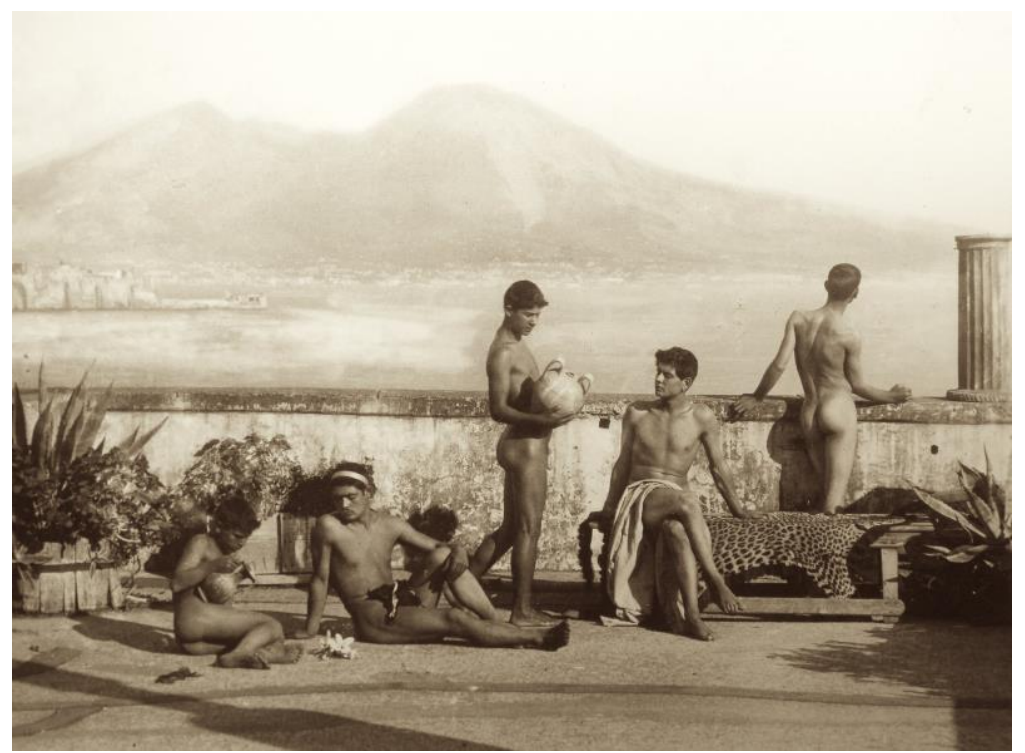

Figure 7. Wilhelm von Gloeden (1856-1931), Land of Fire, c. 1895. Albumen silver print from glass negative, 30 x $40 \mathrm{~cm}$. Private collection. (CC Public Domain Mark 1.0)

And once again we find in von Gloeden's photographs of adolescent boys, as in Sir William's display of fisherboys, the couching, under the guise of classicism, of male desire for male lower-class bodies, and in particular, for southern European bodies with "their dusky skins" (Waugh 93). The same is true of photographs by von Gloeden's cousin Wilhelm von Plüschow, who moved to Naples, and in whose photographs we find a similar aesthetic and subject matter to von Gloeden's. In this context, it becomes impossible to disentangle notions of camp, desire, classicism, and the "intra-European imperialism of the North-South tourist industry" (Waugh 92).

\section{Conclusion}

Rewriting camp into neoclassicism provides us with a more nuanced understanding of neoclassicism and of its development in Sir William Hamilton's circle, and it allows us to follow the vein of campiness within the classical tradition from the eighteenth century onward. As Devoney Looser demonstrates in her article in this issue, a very similar phenomenon is observable with Jane Austen's writings: Looser explores both the effacement of Austen's campiness - even though it has been there in plain sight - and the richness to be gained from reading camp back into Austen's 
writings and their reception. Looser's notion of "Vanilla Camp" is also a productive one in considering the performances in Sir William's Naples. Reinscribing camp into neoclassicism places desire for the lower-class body - both male and femaleand campy performances of gender and sexuality at the birth of the neoclassical aesthetic. Yet the camp component of neoclassicism has been erased in later histories of the movement. In the accompanying volume to the exhibition $L a$ peinture comme crime: la part maudite de la modernité, the art historian and curator Régis Michel argued that Western art had tended toward the denial of "expression, passion, movement. Hatred of the body" (5; my translation) and that Winckelmann, and therefore neoclassicism, had pushed this tendency to its ultimate limit. Identifying camp as an element in the development of neoclassicism allows us not only to think about this foundational art historical moment in a different way, it also makes clear the process of negation that was in play in the neoclassical project and that repressed its own camp aspects in favour of the ideal of timeless, universal truths.

\footnotetext{
${ }^{1}$ The novel, first published in 1954, contains one of the first discussions of camp. Having remarked on the impossibility of defining camp, Charles continues, "You have to meditate on it and feel it intuitively, like Laotse's Tao. Once you've done that, you'll find yourself wanting to use the word whenever you discuss aesthetics or philosophy or almost anything. I never can understand how critics managed to do without it." For Charles, camp is at the basis of, among other phenomena, Baroque art and the ballet: "You're expressing what's basically serious to you in terms of fun and artifice and elegance" (106).

${ }^{2}$ Whether or not parody is a sine qua non of post-eighteenth-century camp lies outside the scope of this essay.

${ }^{3}$ This translation from Winckelmann's Geschichte der Kunst des Alterthums (History of the Art of Antiquity, chap. 4) is by Alice Kuzniar (11). The painting is the forged work depicting Jupiter kissing Ganymede that the neoclassical painter Anton Raphael Mengs had produced to prank his friend Winckelmann. For more on this episode, see Roworth.

${ }^{4}$ For more on Emma Hamilton and her Attitudes, see Contogouris (2018), esp. chapter three.

${ }^{5}$ The construction of his Strawberry Hill House and his novels such as The Castle of Otranto (1764) can both be seen as expressions of camp.

${ }^{6}$ The print medium itself ensured that the images were widely circulated. The album was also reissued in German and British editions for decades. These editions can be found today in libraries around the world.

${ }^{7}$ My thanks to Jonathan Katz for this suggestion.

${ }^{8}$ Campy satires of the connoisseur abounded in this period. See Freya Gowrley's discussion of the macaroni print Refin'd Taste in "Representing Camp: Constructing Macaroni Masculinity in Eighteenth-Century Visual Satire" in this special issue of $A B O$.

${ }^{9}$ Courbet had been reluctant to do so, for he did not believe that art could be taught. As he explained in his "Letter to Young Artists" dated December 25, 1861, he agreed to open a studio but did not wish to enter into a formal teacher-student relationship with its younger members. This letter has come to be viewed as a sort of manifesto of Realism even though Courbet shies from using the term.
} 
ABO: Interactive Journal for Women in the Arts, 1640-1830, Vol. 9 [2019], Iss. 1, Art. 3 


\section{Works Cited}

Cleto, Fabio. "Introduction," Camp: Queer Aesthetics and the Performing Subject: A Reader,edited by Fabio Cleto. Edinburgh UP, 1999.

Contogouris, Ersy. Emma Hamilton and Late Eighteenth-Century European Art: Agency, Performance, and Representation. Routledge, 2018.

Courbet, Gustave. "Lettre aux jeunes artistes." (1861) Courbet raconté par luimême et par ses amis, edited by Pierre Courthion. Cailler, 1950. 2 vols.

Cox, Jeffrey N. Poetry and Politics in the Cockney School: Keats, Shelley, Hunt and their Circle. Cambridge UP, 1998.

Cramer, Charles. Abstraction and the Classical Ideal, 1760-1920. U of Delaware Press, 2006.

Davis, Whitney. "Homoerotic Art Collection from 1750 to 1920." Other Objects of Desire: Collectors and Collecting Queerly, special issue of Art History, edited by Michael Camille and Adrian Rifkin, vol. 24, no. 2, Apr. 2001, pp. 247-77.

Drushel, Bruce E., and Brian M. Peters, editors. Sontag and the Camp Aesthetic: Advancing New Perspectives. Lexington Books, 2017.

Durey, Philippe. La sculpture française au XIX siècle, edited by Christian Germanaz, Éditions de la Réunion des musées nationaux, 1986.

Eisenman, Stephen F. Nineteenth-Century Art: A Critical History. $4^{\text {th }}$ ed. Thames and Hudson, 2011.

Gloyn, Liz. "Naked Youths, Barthes and the Semiotics of the Classical." Classically Inclined, 10 June 2011. https://lizgloyn.wordpress.com/2011/06/10/naked-youths-barthes-and-thesemiotics-of-the-classical/. Accessed 23 Aug. 2017.

Goethe, Johann Wolfgang von, Italian Journey. 1786-1788. Translated by W. H. Auden and Elizabeth Mayer, 1982. Penguin Books, 1996.

Goodman, John. "Paris with Ganymede: A Critical Supplement to Damisch's Judgement." Oxford Art Journal, vol. 28, no. 2, June 2005, pp. 227-44. 
Hales, Shelley, and Joanna Paul. Pompeii in the Public Imagination from its Rediscovery to Today. Oxford UP, 2013.

Halperin, David. How to Be Gay. The Belknap P of Harvard UP, 2014.

Hargrove, June E. "Francisque-Joseph Duret, 1804 Paris 1865." The Romantics to Rodin: French Nineteenth-Century Sculpture from North American Collections, edited by Peter Fusco and H. W. Janson, Los Angeles County Museum of Art, 1980.

Hertz, Neil. "Medusa's Head: Male Hysteria under Political Pressure." Representations, vol. 4, Autumn 1983, pp. 27-54.

Honour, Hugh. Neo-classicism. Penguin Books, Style and Civilization Series, 1991.

Horn, Katrin. Women, Camp, and Popular Culture: Serious Excess. Palgrave Macmillan, 2017.

Hunisak, John. "Images of Workers: From Genre Treatments and Heroic Nudity to the Monument to Labor." The Romantics to Rodin: French NineteenthCentury Sculpture from North American Collections, edited by Peter Fusco and H. W. Janson. Los Angeles County Museum of Art, 1980.

Isherwood, Christopher. The World in the Evening. Avon, 1956.

Jenkins, Ian, and Kim Sloan, editors. Vases and Volcanoes: Sir William Hamilton and His Collection. British Museum P, 1996.

Kuzniar, Alice A., ed. Outing Goethe and His Age. Stanford UP, 1996.

Lada-Richards, Ismene. "“Mobile Statuary': Refractions of Pantomime Dancing from Callistratus to Emma Hamilton and Andrew Ducrow." International Journal of the Classical Tradition, vol. 10, no. 1, Summer 2003, pp. 3-37.

Le Normand Romain, Antoinette. In La sculpture française au XIX siècle, edited by Christian Germanaz. Éditions de la Réunion des musées nationaux, 1986.

Licht, Fred. "Perseus 1804-1806." Canova by David Finn and Fred Licht. 
Abbeville P, 1983.

Looser, Devoney. “Jane Austen Camp.” Eighteenth-Century Camp, Mar. 2016. https://18thcamp.wordpress.com/2016/03/21/jane-austen-camp/. Accessed 15 Aug. 2017.

Marsh, Anne. The Darkroom: Photography and the Theatre of Desire. Macmillan Art Publishing, 2003.

Meyer, Moe. "Introduction: Reclaiming the Discourse of Camp." The Politics and Poetics of Camp, edited by Moe Meyer. Routledge, 1994, pp. 1-19.

Michel, Régis. La Peinture comme crime, ou, la part maudite de la modernité. Réunion des musées nationaux, 2000.

Penrose, Mehl Allan. Masculinity and Queer Desire in Spanish Enlightenment Literature. Routledge, 2016.

Robertson, Pamela. Guilty Pleasures: Feminist Camp from Mae West to Madonna. Bloomsbury, 1996.

Rokeby, John B. S. Morritt of. The Letters of John B. S. Morritt of Rokeby: Descriptive of Journeys in Europe and Asia Minor in the Years 17941796, edited by G. E. Marindin, John Murray, 1914.

Roworth, Wendy Wassyng. "Pulling Parrhasius's Curtain: Trickery and Fakery in the Roman Art World." Regarding Romantic Rome, edited by Richard Wrigley, Peter Lang, 2007, pp. 17-37.

Russell, Bruce. "Wilhelm von Pluschow and Wilhelm von Gloeden: Two Photo Essays.” Studies in Visual Communication, vol. 9, no. 2, Spring 1983, pp. 57-80.

Sontag, Susan. "Notes on Camp." 1964. Republished in Against Interpretation. Farrar, Straus, and Giroux, 1966.

Touchette, Lori-Ann. 'Sir William Hamilton's 'Pantomime Mistress': Emma Hamilton and Her Attitudes." The Impact of Italy: The Grand Tour and Beyond, edited by Clare Hornsby, The British School at Rome, 2000, pp. 123-46. 
Tours, Hugh. The Life and Letters of Emma Hamilton. Victor Gollancz, 1963.

Vigée-Le Brun, Louise-Élisabeth. Souvenirs of Madame Vigée Lebrun, $3^{\text {rd }}$ American ed. Revised and corrected by Morris F. Tyler. Worthington, 1880. 2 vols.

Walpole, Horace. The Yale Edition of Horace Walpole's Correspondence, edited by W. S. Lewis and D. Wallace. Yale UP, 1937-83. 48 vols.

Waugh, Thomas. Hard to Imagine: Gay Male Eroticism in Photography and Film from Their Beginnings to Stonewall. Columbia UP, 1996.

Williams, Kate. England's Mistress: The Infamous Life of Emma Hamilton. Ballantine Books, 2006.

Winckelmann, Johann Joachim. Reflections on the Imitation of Greek Works in Painting and Sculpture. 1755. Translated by Elfriede Heyer and Roger C. Norton. Open Court, 1987. 